\title{
Beneficial and harmful roles of bacteria from the Clostridium genus*
}

\author{
Dorota Samul ${ }^{\bowtie}$, Paulina Worsztynowicz, Katarzyna Leja and Włodzimierz Grajek \\ Department of Biotechnology and Food Microbiology, Poznań University of Life Sciences, Poznań, Poland
}

\begin{abstract}
Bacteria of the Clostridium genus are often described only as a biological threat and a foe of mankind. However, many of them have positive properties and thanks to them they may be used in many industry branches (e.g., in solvents and alcohol production, in medicine, and also in esthetic cosmetology). During the last 10 years interest in application of C. botulinum and C. tetani in medicine significantly increased. Currently, the structure and biochemical properties of neurotoxins produced by these bacterial species, as well as possibilities of application of such toxins as botulinum as a therapeutic factor in humans, are being intensely researched. The main aim of this article is to demonstrate that bacteria from Clostridium spp. are not only pathogens and the enemy of humanity but they also have many important beneficial properties which make them usable among many chemical, medical, and cosmetic applications.
\end{abstract}

Key words: Clostridium spp., biotechnological applications, medical and cosmetic importance, pathogenicity

Received: 18 October, 2013; revised: 02 December, 2013; accepted: 05 December, 2013; available on-line: 29 December, 2013

\section{INTRODUCTION}

Bacteria of the Clostridium genus are anaerobic, Gram-positive, rod-shaped, endospore-forming bacteria. They have been known for a very long time. The first information about them is presented in Epidemics III — the book described by Hippocrates in 430-370 BC. Hippocrates reported on C. histoliticum as a cause of gas gangrene (Mayr, 1969). The main symptom of this disease is swelling of the skin (Nigel et al., 2001). Other diseases caused by $C$. tetani were described by Charles Bell in his book. The information about other diseases caused by $C$. tetani appeared in Essays on the Anatomy and Philosophy of Expression in 1824 (Mayr, 1969). However, bacteria from the Clostridium genera were recognized as a separate starter culture were observed only in the 19th century by Louis Pasteur. He was the first to recognize that bacteria can exist and grow without oxygen. His discovery was a huge revelation in his time. Pasteur called such microorganisms Vibrion butyrique because of the main product of their fermentation pathway and introduced the word "anaerobic" to name life without oxygen. $V$. butyrique was renamed 20 years later as $C$. butyricum by another scientist - Adam Prażmowski (Dürre, 2001).

Bacteria from the Clostridium genera are commonly present in natural environment, e.g. they live in dust, soil, water, bottom sediments and in human and animal alimentary canals (Moriishi et al., 1996). They are most- ly known as pathogenic microorganisms. However, they also play an important role in many fields of industrial metabolite production. Bacteria from Clostridium ssp. are able to ferment divers organic compounds and produce large amounts of gases (carbon dioxide, hydrogen, methane), organic acids (lactic, acetic, butyric, and fumaric acids), and also solvents (butanediol and propanediol) (Buckel et al., 2005). They are also used in medicine and esthetic cosmetology. In the past 10 years an interest in application of $C$. botulinum and $C$. tetani in medicine significantly increased. Currently, the structure and biochemical properties of neurotoxins produced by these bacteria, as well as the possibilities of application of such botulinum toxins as a therapeutic factors in humans, are being intensely researched (Jankovic \& Hallet, 1994; Brin, 1997; Bigalke \& Shoer, 2000; Schiavo et al., 2000; Kreydon et al., 2000; Rosetto et al., 2001; Dressler, 2000). In the literature one can also find information that bacteria from C. sporogenes, C. butyricum, C. perfingens, C. acetobutylicum and $C$. botulinum species can be employed in bacteriocin production (Clarke et al., 1975; Barber et al., 1979; Eklund et al., 1988).

In the bacterial world, in one family there are positive and negative bacteria for human and animal species. It is more interesting when the same bacterial strain plays a double role and is both: harmful and beneficial. This article is a review of some possibilities of applications for the bacteria from Clostridium genera in biotechnological processes (in the chemical and energy industry), in medicine and cosmetic, and about pathogenicity of these bacteria.

\section{THE USE OF BACTERIA OF THE CLOSTRIDIUM GENUS IN THE CHEMICAL INDUSTRY}

Bacteria of the Clostridium genus are able to employ intense fermentation metabolism (Jiang et al., 2009; Masset et al., 2010). They are able to produce wide range of metabolites, including: 1,3-propanediol (Biebl et al., 1998; Kubiak et al., 2012), acetic acid, butyric acid, formic acid (Wu \& Yang, 2003; Song, 2011), ethanol, butanol, acetone (Jones \& Woods, 1986; Ezeji et al., 2003), carbon dioxide (Khanal et al., 2004), hydrogen and ammonia (Levin et al., 2006; Ren et al., 2007; Skonieczny \& Yargeau, 2009; Oh et al., 2009; Beckers et al., 2010). The

e-mail: dorota.orczyk@up.poznan.pl

*Presented at the 3-rd Workshop on Microbiology "MIKROBIOT $2013^{\prime \prime}$ in Łódź, Poland.

Abbreviations: ACh, acetylcholine; BoNT, botulinum neurotoxin; BoNT-A/BTX-A, botulinum toxin type A; BDEPT, bacterial directed enzyme prodrug therapy; COBALT, combination of bacteriolytic therapy; LD50, lethal dose; C., Clostridium; 1,3-PD, 1,3-propanediol; V., Vibrion; S., Salmonella 


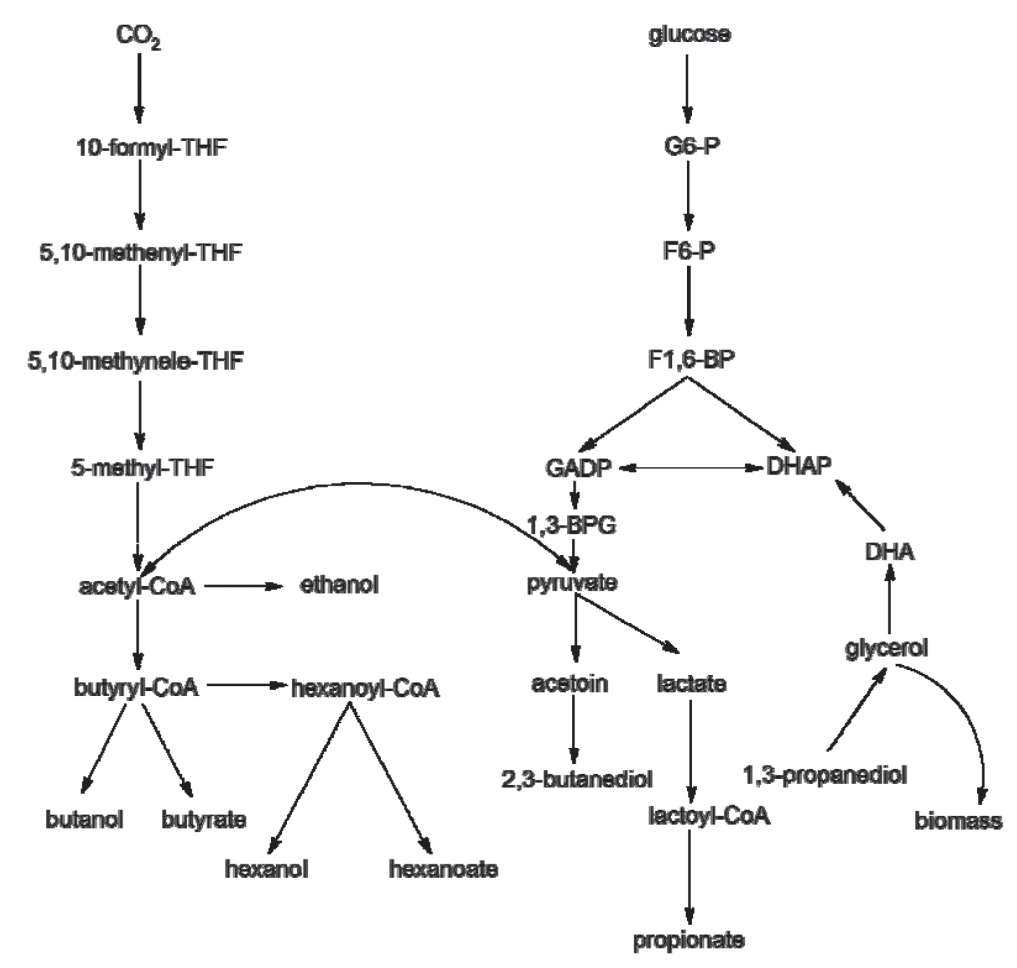

Figure 1. Metabolic pathways of bacteria from the Clostridium genera

metabolic pathway of production of metabolites by the Clostridium genus bacteria is shown in Fig. 1.

\section{Production of 1,3-propanediol}

1,3-propanediol (1,3-PD) is a three-carbon diol which consists of two hydroxyl groups on the primary carbon atoms, with the formula $\mathrm{C}_{3} \mathrm{H}_{8} \mathrm{O}_{2}$. 1,3-PD is also known as a trimethylene glycol, 1,3-dihydroxypropane, propane-1,3-diol. 1,3-PD is an important chemical by-product in polymer production (Igari et al., 2000; Drożdżyńska et al., 2011). 1,3-PD is one of the oldest known fermentation products. This diol was identified in 1881 by August Freund, as a product of glycerol fermentation by C. pasterianum. In the past, 1,3-PD was produced only via chemical methods (Igari et al., 2000). Nowadays, an attractive alternative for chemical synthesis is a microbial conversion of 1,3PD from renewable resources (Nakamura et al., 2003; $\mathrm{Mu}$ et al., 2006). A number of microorganisms can grow on glycerol as the sole carbon and energy source and produce 1,3-PD. A large group of these microorganisms are bacteria of the Clostridium genus. This group includes: C. diolis, C. acetobutylicum, C. perfingens, C. butyricum, C. pasteurianum (Biebl et al., 1998; Hao et al., 2008; Kubiak et al., 2012). C. butyricum is the best wild strain to produce 1,3-PD (Wilkens et al., 2012). This strain is characterized by high productivity and little nutrition requirements (Buckel, 2005; Drożdżyńska et al., 2011).

Bacteria of the Clostridium genus are also able to synthesize 1,3-PD with the use of metabolic engineering. Metabolic engineering of the microbial production of 1,3-PD concerns native producers of 1,3-PD (C. butyricum) as well as heterologous hosts (C. acetobutylicum) - microorganisms which are able to form 1,3PD via genetic manipulations (Celińska, 2010; Leja et al., 2011).

\section{Production of organic acids}

Organic acids are low-molecular weight compounds which are found in all organisms and which are characterized by the possession of one or more carboxyl groups (Jones, 1998). Organic acids are among the candidate replacements for in-feed antibiotics. Some of acids (lactic, acetic) have a long history of use in food preservatives (Skrivanova et al., 2006). Bacteria of the genus Clostridium (C. butyricum, C. beijerinckii, C. populeti, C. propionicum, C. thermobutyricum, C. tyrobutyricum) are able to synthesize organic acids: succinic acid, acetic acid, butyric acid and propionic acid (Johns, 1952; Luers et al., 1997; Zhu et al., 2002; Willims et al., 2003). Butyric acid is widely used in the chemical industry (for the synthesis of polymers of butyryl), pharmaceutical, and especially in the food industry to strengthen butter notes of flavor in food products (Zigova et al., 1999; Wu \& Yang, 2003; Liu et al., 2006). Butyric acid is produced mainly by oxidation of butyraldehyde obtained from oxosynthesis of propylene (Wu \& Yang, 2003). Propionic acid is widely used as an antifungal agent in food, beer and as an intermediate in the synthesis of herbicides, cellulose acetate (propionate plastics), solvents and pharmaceuticals (Kośmider et al., 2010). In contrast to propionate production in Propionibacterium, which is produced through decarboxylic acid pathway, propionate in C. propionicum can be produced through the acrylate pathway (Tracy et al., 2012). There are two major areas of commercial application of acetic acid today: food-grade vinegar and chemically synthesized industrial acetic acid. Among the bacteria of the Clostridium genus, $C$. thermoaceticum is able to synthesize acetic acid from xylobiose (Nakamura et al., 2011). Biosynthetic routes often have product-specific advantages over chemical synthesis, which are important for extending and adding value to products.

\section{Production of solvents}

Solvents are liquids which form a homogeneous system (solution) with the substances dissolved in them. It is well known for almost 100 years that bacteria can produce solvents by fermentation. In the 1920s biotechnological production of solvents has been replaced by petrochemical methods. In the 1960s fermentation which used bacteria of the Clostridium genus was completely eliminated from industry. Clostridium ssp. were eliminated because the process was characterized by low productivity, low yield and high cost of the product recovery. Nevertheless, this method cannot be forgotten altogether. Currently, we can see an internationally growing concern for the environment and the need to gain independence from the petrochemical industry. This tendency led to an increased interest in the production of solvents from natural raw materials (e.g. corn, soy, molasses, wood hydrolysates etc.). A lot of research in this area has made the process competitive (Jones et al., 1982; Dabrock et al., 1992; Qureshi et al., 2000).

Bacteria of the Clostridium genus are able to synthesize solvents such as acetone, butanol and ethanol. This 
group includes: C. acetobutylicum, C. pasteurianum, C. beijerinckii, C. saccharoperbutylacetonicum and C. saccharobutylicum, C. sporogenes Johnson et al., 1997; Keis et al., 2001; Bankar et al., 2012; Sun \& Liu, 2012; Tracy et al., 2012; Gottumukkala et al., 2013). C. beijerinckii is able to produce isopropanol in addition to butanol (George et al., 1983; Chen \& Hiu, 1986). Instead, C. pasterianum ferments hydrocarbons to butanol, acetone, carbon dioxide and hydrogen (Heyndrickx et al., 1991; Dabrock et al., 1992).

For the production of solvents, acetylo-CoA and butyrylo-CoA are the key intermediate factors to obtain ethanol and butanol. Acetyl-CoA is the key intermediate factor to produce acetone (Harris et al., 1999; Kasap, 2002).

\section{THE USE OF BACTERIA OF THE CLOSTRIDIUM GENUS IN THE ENERGY INDUSTRY}

Energy is the source of all human activity. In nature, energy is never lost but it is changing its form. There are many different ways in which energy can be stored, converted and amplified for our use (Demirbaş, 2001).

\section{Production of hydrogen}

Hydrogen is the element which is a very efficient source of energy, the energy equal to $33 \mathrm{Whg}^{-1}$. Hydrogen is regarded as one of the most important sources of energy. It can be also converted into energy in combustion engines, fuel cells and as a component of rocket fuel. Hydrogen is produced mainly by chemical methods (Chin et al., 2003). Currently, 90\% of total production is obtained either from methane or electrolysis of water. However, the ability of using microorganisms in hydrogen production has been intensly investigated. Among others, direct and indirect biophotolysis, photofermentation and dark fermentation have been examined (Levin, 2006; Lo et al., 2010). Among promising solutions for biological hydrogen production there is hydrogen fermentation. Among numerous groups of microorganisms which are able to produce hydrogen, bacteria of the Clostridium genus, especially C. acetobutylicum and C. butyricum, are typically used (Chin et al., 2003; Chen et al., 2005).

The reaction of molecular hydrogen formation is as follows (Khanal et al., 2004):

$\mathrm{C}_{12} \mathrm{H}_{22} \mathrm{O}_{11}+5 \mathrm{H}_{2} \mathrm{O} \rightarrow 4 \mathrm{CH}_{3} \mathrm{COOH}+4 \mathrm{CO}_{2}+8 \mathrm{H}_{2}$ $\mathrm{C}_{12} \mathrm{H}_{22} \mathrm{O}_{11}+\mathrm{H}_{2} \mathrm{O} \rightarrow 2 \mathrm{CH}_{3} \mathrm{CH}_{2} \mathrm{CH}_{2} \mathrm{COOH}+4 \mathrm{CO}_{2}+4 \mathrm{H}_{2}$.

However, in this group of microorganisms there are also strains which are able to produce hydrogen not only from glycerol, but also from xylose - C. tyrobutyricum (Liu et al., 2006) and from cellulosic substrates - $C$. thermocellum (Levin et al., 2006).

\section{Biomass conversion}

Biomass is a term used for all organic material that stems from plants (McKendry, 2002a). Biomass is the oldest energy source used by humans. Traditionally, biomass has been utilized through direct combustion and this process is still widely used in many parts of the world. Historically, biomass has been dispersed, labor intensive and land intensive source of energy. Biomass differs from other alternative energy sources in that this resource is diversified. Biomass can include wastes, standing forests and energy crops. It can be converted to energy through a number of conversion processes (Demirbaş, 2001). Conversion of biomass to energy can employ two main technologies - thermochemical and biological (McKendry, 2002b).
Many microorganisms are able to utilize a variety of carbohydrates for the conversion of lignocellulose biomass to bioenergy. Pectinolytic bacteria of the Clostridium genus seem to be especially attractive in this aspect of biomass conversion. In contrast to the hyperthermophilic microorganisms (Caldicellulosiruptor kristjanssonii, Anaerocellum thermophilum), bacteria of the Clostridium genus are less thermophilic. This group of bacteria includes numerous species that utilize crystalline cellulose, as well as hemicellulose, as growth substrates (Blumer-Schuette et al., 2008). C. flavum, C. laniganii during fermentation of pectins loosen the plant tissue and allow fast separation of the cellulose fibers (Lanigan, 1959). These groups of microorganisms are of great importance to biomass degradation.

\section{SOME APPLICATIONS OF THE CLOSTRIDIUM GENUS IN MEDICINE AND COSMETICS}

Over the past few years botulinum neurotoxin (BoNT) has transformed from a cause of life-threatening affliction to a medical therapy. In 1978, Dr. Alan Scott was the first to use BoNT-A in humans for treatment of strabismus. Nowadays, after elucidating the pharmacological mode of the botulinum toxin action, it has become possible to use it in a wide spectrum of health disorders (Mahajan \& Brubaker, 2007).

There are seven types of immunologically distinct serotypes of botulinum neurotoxin (BoNT): A, B, C1, D, $\mathrm{E}, \mathrm{F}$, and $\mathrm{G}$. Toxins produced by clostridial bacteria are high-molecular-weight protein complexes. Each toxin is antigenically distinct, but they have similar molecular weights of $150 \mathrm{kD}$, as well as structures. All the toxins consist of a light and heavy chain linked by a disulfide bond. BoNT acts by blocking the release of acetylcholine $(\mathrm{ACh})$ at the neuromuscular junction and it results in flaccid paralysis of the treated muscle (Johnson \& Bradshaw, 2001; Majid, 2010; Tsui, 1996; Wheelera \& Smith, 2013).

Botulinum toxin is effective in the treatment of some pain syndromes, e.g. BoNT can selectively weaken painful muscles by interrupting the spasm pain cycle. BoNT-A is well tolerated in the treatment of chronic pain disorders in which pharmacotherapy can cause side effects, such as migraines, chronic lumbar pain, tension headaches and myofascial pain. The reduction in the consumption of analgesics and length of action of three to four months per dose represent other advantages of its use (Colhado et al., 2009).

Types $\mathrm{A}$ and $\mathrm{B}$ of the toxins can also be used in the treatment of strabismus, blepharospas, nystagmus, vocal tics and stuttering, various manifestations of tremor, facial muscle contraction and many other dystonias, including cervical focal dystonias.

Additionally, injections of the botulinum toxin are among the latest means of therapy in treatment of neurological diseases (spasticity, in particular cerebral palsy, Parkinson's disease, Tourette's syndrome), gastroenterological diseases (achalasia), urological diseases (detrusorsphincter dyssynergia, detrusor instability, lower urinary tract dysfunction), ophthalmological (strabismus) or dermatological diseases (hyperhidrosis, facial flushing). Treatment of muscle hyperactivity by injecting BTX-A into selected muscles produces dose-dependent chemical denervation resulting in reduced muscular activity (Barnes et al., 2011; Friedmana \& Potulska, 2001; Graham et al., 2000; Lin, 2007; Sutcliffe et al., 2005; Tsui, 1996). For example, in a recent study of 30 patients with 
Tourette's syndrome and phonic tics, injection of the botulinum toxin improved symptoms in 93\% and helped to improve the patients' quality of life (Sutcliffe et al., 2005).

Moreover, not only metabolites of bacteria of the Clostridium genus, but also whole bacterial cells are used for medical therapy. Several studies have demonstrated that they can be used as probiotic agents against internal hemorrhages caused by enterohaemorrhagic Escherichia coli. Furthermore, they inhibit the growth of C. difficle, S. typhimurium and Vibrio spp (Nigel et al., 2001; Ranade, 1989).

In recent years, there have been reports on the use of natural and engineered non-pathogenic bacterial species as potential antitumor agents, either to deliver tumoricidal molecules or to provide direct tumoricidal effects. Currently, the interest in alternative methods of cancer treatment is high because traditional cancer therapies have limited effectiveness due to poor penetration that reduces the dose present throughout tumors and due to the lack of selectivity to cancer cells which results in causing damage to normal tissue (Minton et al., 1995; Barbé et al., 2006; St Jean at al., 2008; Patyar at al., 2010).

Bacteria have the potential to overcome these limitations by actively targeting all tumor regions and delivering therapeutic payloads. The high specificity for cells of solid tumors is based on hypoxic tumors regions. Normal tissues are well oxygenated which prevents germination and growth of anaerobic bacteria whereas the hypoxic tumor regions allow the germination of spores and vegetative cell proliferation. Live, attenuated or engineered non-pathogenic bacterial species are capable of multiplying selectively in tumors and inhibiting their growth (Mellaert at al., 2006; Patyar at al., 2010; Wei at al., 2008). Research on C. noyyi (attenuated strain) showed significant anti-tumor effects, but these experiments also led to death.

The use of combination of bacteriolytic therapy (COBALT) also resulted in anti-tumor effects, but still was not devoid of animals' death. C. noyyi has been investigated in conjunction with chemotherapy, radiotherapy and radioimmunotherapy.

Bacteria are also able to produce and secrete proteins, which can be combined with targeting in order to apply a focused therapy. Using proteins with different functionality, there are three methods of bacterial treatment that can be adjusted: enzymatic drug activation, controlled cytotoxicity and biomolecule secretion (St Jean at al., 2008).

First strategy, called bacterial directed enzyme prodrug therapy (BDEPT) involves the tumor-specific location of bacteria to locally activate systemically administered 'prodrugs' within the tumor. BDEPT is a two-step therapy. First, recombinant spores carrying the genetic information about recombinant proteins are injected into the patient's body and they are targeted to the site of the tumor where the enzyme is expressed. Next, once the levels of enzyme expression are optimal, prodrugs are administered and are converted to a cytotoxic drug by the expressed enzyme strictly at the tumor site (Lehouritis et al., 2013). The last strategy involves producing biologically active molecules to induce a physiological response. Studies have shown that Clostridum can be designed to produce therapeutically significant levels of a cytokine, interleukin-2, which causes T-cell-mediated neoplastic death.

Over the past decade, facial cosmetic procedures have become more common place in maxillofacial and oral surgery and dentistry. One of the most often requested procedures is a treatment with botulinum toxin type A (BoNT-A), which is known under several names such as Botox, Dysport.

The most common cosmetic procedure performed by intramuscular injection of BoNT is aimed to reduce facial wrinkles. Facial wrinkles are formed primarily due to intensive work of leading muscles, wrinkling one's brows and longitudinal muscle. Treatment of facial wrinkles involves injecting into the muscle different doses of the botulinum toxin, which reduces facial muscle activity. A significant improvement in facial skin tension is observed in approximately $90 \%$ of patients. The first effect of such a therapy is observed after 1-4 days, and a maximum after 2-3 weeks. The final effect is obtained after 3-6 months of therapy. Another procedure carried out with the use of botulinum toxin is correction of Masseteric hypertrophy. Masseteric hypertrophy usually results from anatomical asymmetry of the jaw, habitual asymmetric use of the jaw, excessive chewing of gum, clenching during exercise or sleep, and congenital malformations. The results of treatment with intramasseter injections of botulinum toxin have been encouraging and satisfying to patients (Jaspers et al., 2011; Majid, 2010).

Additionally, the botulinum toxin is used in treatment of glabellar lines, frontalis muscle, commuter lines, smile orbital resin and masseter muscle hypertrophy. Recently, the therapeutic utility of the botulinum toxin in the treatment of excessive sweating was reported (Sutcliffe et al., 2005).

\section{Pathogenicity}

Many bacteria of the Clostridium genus have adverse effects on food products and human health. The Clostridium genus includes 35 species of pathogens producing exotoxins, including C. botulinum, C. perfringens, C. tetani, C. barati, C. haemolyticum, C. novyi, C. septicum, C. chanvoei and C. difficile (Moriishi et al., 1996). The most well-known pathogen of the Clostridium genus is $C$. botulinum that causes botulism. Botulism is caused by a botulinum neurotoxin (BoNT) produced from the anaerobic, spore-forming bacterium C. botulinum (Shapiro et al., 1998). The most common cause of poisoning in humans are neurotoxins type A, B, and E (Bielec \& Modrzewska, 2007; Wheeler \& Smith, 2013). BoNT is a very strong poison, for example it is $10^{12}$ more lethal than sodium cyanide. The estimated LD50, for humans (assuming a body weight of $70 \mathrm{~kg}$ ), extrapolated from experiments on animals, has been estimated to be approximately 70 $\mu \mathrm{g}$ by oral administration, $0.09-0.15 \mu \mathrm{g}$ to intravenous administration and $0.7-0.9 \mu \mathrm{g}$ by inhalation (Majid, 2010; Tsui, 1996). The disease can be divided into six types - foodborne botulism, wound botulism, infant botulism, adult intestinal toxemia botulism, inhalation botulism and iatrogenic botulism (Cherington, 1998; Bielec \& Modrzewska, 2007). All forms of botulism produce the same distinct clinical syndrome. Botulism leads to paralysis that usually starts with the muscles of the face and then spreads towards the limbs. In severe forms, it leads to paralysis of the breathing muscles and causes respiratory failure, which may lead to death (Aureli et al., 2008; Sobel, 2005).

Foodborne botulism is due intoxication caused by consuming food contaminated with the botulinum toxin. However, wound botulism is caused by contamination of wound with $C$. botulinum spores and subsequent germination of these spores and production of 
toxin in the anaerobic milieu of an abscess. The toxin is partially absorbed into the blood (Mahajan \& Brubaker, 2007; Sobel, 2005).

Infant botulism occurs in infants between 1 week and 11 months of age and is a combination of infection and intoxication, including ingestion of $C$. botulinum spores, germination within the gastrointestinal tract and in vivo production of toxin (Caya et al., 2004; Jagoda \& Renner, 1990). In part due to the immaturity of the child's intestinal flora and in part due to a relatively low production of clostridial-inhibiting bile acid as compared to the adult gastrointestinal tract, this factor promotes development of the disease. A significant risk factor for the development of infant botulism is honey consumption, because $15 \%$ to $25 \%$ of honey products harbor botulinum spores. Therefore, children under one year of age should not eat honey at all (Caya et al., 2004; Moriishi et al., 1996; Bielec \& Modrzewska, 2007).

Adult intestinal toxemia botulism is caused by the colonization of the colon by C. botulinum producing BoNT in situ and its absorption into the blood. The emergence of this form of botulism is caused by the presence of earlier lesions in the gastrointestinal tract: disturbance of bacterial flora composition after antibiotic therapy, a condition after a surgical operation or chronic gastrointestinal inflammatory bowel diseases (Bielec \& Modrzewska, 2007).

Iatrogenic botulism is an extremely rare form of the disease that is caused by intake of BoNT A in the form of injection. The symptoms are usually limited to generalized muscle weakness, slight drooping of eyelids, double vision or dryness of mucous membranes in the mouth. Inhalation of botulinum toxin does not occur naturally in the natural environment. We all know the case from 1962, where in one of the laboratories in Germany three employees were infected. All those who became ill were exposed to an aerosol containing BoNT A. All of them had symptoms similar to foodborne botulism (Bielec \& Modrzewska, 2007).

Like C. botulinum, bacteria of the C. tetani and $C$. sordellii species are dangerous for human health. Infections of those bacteria cause acute diseases and pose difficult clinical challenges. C. tetani causes tetanus. C. tetani usually enters the body through a wound and spores start to germinate. Toxins are produced and disseminated via blood and lymphatics. Tetanus is characterized by generalized rigidity and convulsive spasms of skeletal muscles.

C. sordellii infections are usually fatal. Most commonly, these infections occur after trauma, childbirth, and routine gynecological procedures, but they have recently been associated with medically induced abortions and injection drug use (Aldape et al., 2006).

C. difficle causes nosocomial infections associated with food. Strains that exhibit disease produce two different protein toxins: a strong cytotoxin and an enterotoxin causing diarrhea; they are released by the vegetative cells (Bielec \& Modrzewska, 2007).

C. perfingens causes gas gangrene and is the cause of severe food poisoning, associated with the release of enterotoxin by vegetative cells. In the development of gas gangrene other species of Clostridium are involved, including $C$. novyi and C. septicum (Stackebrandt \& Hippe, 2001).

\section{CONCLUSIONS}

The Clostridium genera consist of many bacterial species with a wide range of physiological properties, thanks to which they may be used in many branches of the industry. Despite the fact that a lot of Clostridium species are pathogenic, some of them are used in medicine, in cancer treatment, and in cosmetology to remove wrinkles. Moreover, enzymes isolated from these bacterial cells are commonly used in modern biotechnology.

The important issue is to demonstrate that bacteria from Clostridium spp. are not only pathogens and the enemy of humanity but they also have many beneficial and important properties which make them usable among other chemical, medical, and cosmetic applications.

\section{Acknowledgement}

The paper was prepared within the framework of project no. 01.01.02-00-074/09 co-funded by The European Union from The European Regional Development Fund within the framework of the Innovative Economy Operational Programme 2007-2013.

\section{REFERENCES}

Aldape MJ, Bryant AE, Stevens DL (2006) Clostridium sordellii infection: Epidemiology, clinical findings, and current perspectives on diagnosis and treatment. Clin Infect Dis 43: 1436-1446.

Aureli P, Franciosa G, Fenicia L (2008) Botulism. International Encyclopedia of Public Health 329-337.

Bankar SB, Survase SA, Singhal RS, Granström T (2012) Continuous two stage acetone-butanol-ethanol fermentation with integrated solvent removal using Clostridium acetobutylicum B 5313. Bioresource Technol 106: 110-116.

Barbé S, Van Mellaert L, Anné J (2006) The use of clostridial spores for cancer treatment. I Appl Microbiol 101: 571-578.

Barber JM, Robb FT, Webster JR, Woods DR (1979) Bacteriocin production by Clostridium acetobutylicum in an industrial fermentation process. Appl Environ Microb 37: 433-437.

Barnes MA, Ho AS, Malhotra PS, Koltai PJ, Messner A (2011) The use of botulinum toxin for pediatric cricopharyngeal achalasia. Int J Pediatr Otorhi 75: 1210-1214.

Beckers L, Hiligsmann S, Hamilton Ch, Masset J, Thonart P (2010) Fermentative hydrogen production by Clostridium butyricum CWBI1009 and Citrobacter freundii CWBI952 in pure and mixed cultures. Biotechnol Agron Soc Environ 14 (S2): 541-548.

Biebl H, Zeng AP, Menzel K, Deckwer WD (1998) Fermentation of glycerol to 1,3-propanediol and 2,3-butanediol by Klebsiella pneumonia. Appl Microbiol Biot 50: 24-29.

Bielec D, Modrzewska R (2007) A history of botulin toxin diseases - clinical aspects. Epidemiologic Rev 61: 505-512 (in Polish).

Bigalke H, Shoer LF (2000) "Clostridial neurotoxins" in Bacterial Protein Toxins In Handbook of Experimental Pharmacology, Aktories K, Just I eds. 145: 407-443. Springer-Verlag, Berlin.

Blumer-Schuette SE, Kataeva I, Westpheling J, Adams MWW, Kelly RM (2008) Extremely thermophilic microorganisms for biomass conversion: status and prospects. Curr Opin Biotechnol 19: 210-217.

Brin MF (1997) Botulinum toxin: chemistry, pharmacology, toxicity, and immunology. Muscle \& Nerve 20: 156-168.

Buckel W (2005) Special "Clostridial enzymes and fermentation pathways" In Handbook on Clostridia, p 81. CRC Press LLC, Boca Raton.

Caya JG, Agni R, Miller JE (2004) Clostridium botulinum and the clinical laboratorian: a detailed review of botulism, including biological warfare ramifications of botulinum toxin. Arch Pathol Lab Med 128: 653-662.

Celińska E (2010) Debottlenecking the 1,3-propanediol pathway by metabolic engineering. Biotechnol Adv 28: 519-530.

Chen JS, Hiu SF (1986) Acetone-butanol-isopropanol production by Clostridium beijerinckii (synonym Clostridium butylicum). Biotechnol Lett 8: 371-376.

Chen WM, Tseng ZJ, Lee KS, Hang JS (2005) Fermentative hydrogen production with Clostridium butyricum CGS5 isolated from anaerobic sewage sludge. Int J Hydrogen Energ 30: 1063-1070.

Cherington M (1998) Clinical spectrum of botulism. Muscle Nerve 21: 701-710.

Chin HL, Chen ZS, Chou CP (2003) Fed-batch operation using Clostridium acetobutylicum suspension culture as biocatalyst for enhancing hydrogen production. Biotechnol Progr 19: 383-388. 
Clarke DJ, Moyra RR, Morris JG (1975) Purification of two Clostridium bacteriocins by procedures appropriate to hydrophobic proteins. Antimicrob Agents Chemother 3: 256-264.

Colhado OCG, Boeing M, Ortega LB (2009) Toxina botulínica no tratamento da dor botulinum toxin in pain treatment. Rev Bras Anestesiol 59: 366-381.

Dabrock B, Bahl H, Gottschalk G (1992) Parameters affecting solvent production by Clostridium pasteurianum. Appl Environ Microb 58: 1233-1239.

Demirbaş A (2001) Biomass resource facilities and biomass conversion processing for fuels and chemicals. Energ Convers Manage 42: $1357-1378$

Dressler D (2000) Botulinum toxin therapy, pp 64-67. Theme-Verlag, Stuttgard.

Drożdżyńska A, Leja K, Czaczyk K (2011) Biotechnological production of 1,3-propanediol from crude glycerol. J Biotechnol, Comput Biol Bionanotechnol 92: 92-100.

Dürre P (2001) From Pandora's Box to Cornucopia: Clostridia - A Historical Perspective in Clostridia: biotechnology and medical applications, Bahl H, Dürre P eds, pp 1-6; 20-22. Wiley-VCH Verlag GmbH, Germany.

Eklund FT, Poysky LM, Mseitif T, Strom MT (1988) Evidence for plasmid-mediated toxin and bacteriocin production in Clostridium botulinum Type G. Appl Environ Microb 54: 1405-1408.

Ezeji TC, Qureshi N, Blaschek HP (2003) Production of acetone, butanol and ethanol by Clostridium beijerinckii BA101 and in situ recovery by gas stripping. World J Microb Biot 19: 595-603.

Friedmana A, Potulska A (2001) Quantitative assessment of parkinsonian sialorrhea and results of treatment with botulinum toxin. Parkinsonism Relat D 7: 329-332.

George HA, Johnson JL, Moore WEC, Holdeman LV, Chen JS (1983) Acetone, isopropanol and butanol production by Clostridium beijerinckii (syn. C. butylicum) and Clostridium aurantibutyricum. Appl Environ Microb 45: 1160-1163.

Glass GE, Hussain M, Fleming ANM, Powell BWEM (2009) Atrophy of the intrinsic musculature of the hands associated with the use of botulinum toxin-A injections for hyperhidrosis: a case report and review of the literature. J Plast Reconstr Aesthet Surg 62: 274-276.

Gottumukkala LD, Parameswaran B, Valappil SK, Mathiyazhakan K, Pandey A, Sukumaran RK (2013) Biobutanol production from rice straw by a non acetone producing Clostridium sporogenes BE01. Bioresource Technol 145: 182-187.

Graham HK, Aoki KR, Autti-Rämö I, Boyd RN, Delgado MR, Gaebler-Spira DJ, Gormley Jr ME, Guyer BM, Heinen F, Holton AF, Matthews D, Molenaers G, Motta F, Garc1 Ruiz PJ, Wissel J (2000) Recommendations for the use of botulinum toxin type $A$ in the management of cerebral palsy. Gait Posture 11: 67-79.

Hao J, Wei W, Jiesheng T, Jilun L, Dehua L (2008) Decrease of 3-hydroxypriopionaldehyde accumulation in 1,3-propanediol production by over-expressing dhaT gebe in Klebsiella pneumonia TUAC01. I Ind Microbiol Biot 35: 735-741.

Harris LM, Desai RP, Welker NE, Papoutsakis ET (1999) Characterization of recombinant strains of the Clostridium acetobutylicum butyrate kinase inactivation mutant: Need for new phenomenological models for solventogenesis and butanol inhibition. Biotechnol Bioeng 67: 1-11.

Heyndrickx, M, De Vos P, Vancanneyt M, De Ley J (1991) The fermentation of glycerol by Clostridium butyricum LMG $1212 \mathrm{t}_{2}$ and 1213 $\mathrm{t}_{1}$, and C. pasteurianum LMG 3285. Appl Microbiol Biot 34: 637-642.

Igari S, Mori S, Takikawa Y (2000) Effects of molecular structure of aliphatic diols and polyalkylene glycol as lubricants on the wear of aluminum. Wear 244: 180-184.

Jagoda A, Renner G (1990) Infant botulism: Case report and clinical update. AM J Emerg Med 8: 318-320.

Jankovic J, Hallet M (1994) Therapy with botulinum toxin. Marcel Dekker, Inc, New York.

Jaspers GWC, Pijpe J, Jansma J (2011) The use of botulinum toxin type A in cosmetic facial procedures. Int J Oral Max Surg 40: 127133.

Jiang L, Wang J, Liang S, Wang X, Cen P, Xu Z (2009) Butyric acid fermentation in a fibrous bed bioreactor with immobilized Clostridium tyrobutyricum from cane molasses. Bioresource Technol 100: 34033409 .

Johns AT (1952) The mechanism of propionic acid formation by Clostridium propionicum. J Gen Microbiol 6: 123-127.

Johnson EA, Bradshaw M (2001) Clostridium botulinum and its neurotoxin: a metabolic and cellular perspective. Toxicon 39: 1703-1722.

Johnson JL, Toth J, Santiwatanakul S, Chen JS (1997) Cultures of Clostridium acetobutylicum from various collections comprise Clostridium acetobutylcium, Clostridium beijerinckii and two other distinct types based on DNA-DNA reassociation. Int J Syst Bacteriol 47: 420-424.

Jones DL (1998) Organic acids in the rhizosphere - a critical review. Plant Soil 205: 25-44.

Jones DT, van der Westhuizen A, Long S, Allcock ER, Reid SJ, Woods DR (1982) Solvent production and morphological changes in Clostridium acetobutylicum. Appl Environ Microb 43: 1434-1439.

Jones DT, Woods DR (1986) Acetone-butanol fermentation revisited. Microbiol Rev 50: 481-524.
Kasap M (2002) Nitrogen metabolism and solvent production in Clostridium beijerinckii NRRL B593. Ph.D. dissertation. Virginia Polytechnic Institute and State University, Blacksburg, Virginia, USA.

Keis S, Shahneen R, Jones D (2001) Emended descriptions of Clostridium acetobutylicum and Clostridium beijerinckii, and descriptions of Clostridium saccharoperbutylacetonicum sp. nov. and Clostridium saccharobutylicum sp. nov. Int J Syst Evol Micr 51: 2095-2103.

Khanal SM, Chen WH, Sung S (2004) Biological hydrogen production: effects of $\mathrm{pH}$ and intermediate products. Int $J$ Hydrogen Energ 29: 1123-1131.

Kośmider A, Drożdżyńska A, Blaszka K, Leja K, Czaczyk K (2010) Propionic acid production by Propionibacterium freudenreichii ssp. shermanii using industrial wastes: crude glycerol and whey lactose. Polish J of Environ Stud 19: 1249-1253.

Kreydon OP, Geiges ML, Boni R, Burg G (2000) Botulinum toxin: from poison to medicine. A historical review. Hautaryt 51: 733-737.

Ksibi I, Godard AL, Azouvi P, Denys P, Dziri C (2009) Botulinum toxin and refractory non-neurogenic overactive detrusor. Ann Phys Rehabil Med 52: 668-683.

Kubiak P, Leja K, Myszka K, Celińska E, Spychała M, SzymanowskaPowałowska D, Czaczyk K, Grajek W (2012) Physiological predisposition of various Clostridium species to synthetize 1,3-propanediol from glycerol. Process Biochem 47: 1308-1319.

Lanigan GW (1959) Studies on the pectinolytic anaerobes Clostridium flavum and Clostridium laniganii. I Bacteriol 77: 1-9.

Lehouritis P, Springer C, Tangney M (2013) Bacterial-directed enzyme prodrug therapy. J Control Release 170: 120-131.

Leja K, Czaczyk K, Myszka K (2011) The use of microorganisms in 1,3-propanediol production. African J Microbiology Res 5: 4652-4658.

Levin BD, Islam R, Cicek N, Sparling R (2006) Hydrogen production by Clostridium thermocellum 27405 from cellulosic biomass substrates. Int J Hydrogen Energ 31: 1496-1503.

Liu X, Zhu Y, Yang ST (2006) Butyric acid and hydrogen production by Clostridium tyrobutyricum ATCC 25755 and mutants. Ensyme Microb Tech 38: 521-528.

Lo YCh, Lu WCh, Chen ChY, Chang JS (2010) Dark fermentative hydrogen production from enzymatic hydrolysate of xylan and pretreated rice straw by Clostridium butyricum CGS5. Bioresource Technol 101: $5885-5891$.

Luers F, Seyfried M, Daniel R, Gottschalk G (1997) Glycerol conversion by glycerol fermentation by Clostridium pasteurianum: cloning and expression of the gene encoding 1,3-propanediol dehydrogenase. FEMS Microbiol Lett 154: 337-345.

Mahajan ST, Brubaker L (2007) Botulinum toxin: from life-threatening disease to novel medical therapy. Am J Obstet Gynecol 196: 7-15.

Majid OW (2010) Clinical use of botulinum toxins in oral and maxillofacial surgery. Int J Oral Max Surg 39: 197-207.

Masset J, Hiligsmann S, Hamiltoa Ch, Beckers L, Franck F, Thonart $\mathrm{P}$ (2010) Effect of $\mathrm{pH}$ on glucose and starch fermentation in batch and sequenced-batch mode with a recently isolated strain of hydrogen-producing Clostridium butyricum CWBI1009. Int J Hydrogen Energ 35: 3371-3378.

Mayr E (1969) Principles of systematic zoology. McGraw-Hill, New York.

McKendry P (2002 a) Energy production from biomass (part 1): overview of biomass. Bioresource Technol 83: 37-46.

McKendry P (2002 b) Energy production from biomass (part 2): conversion technologies. Bioresource Technol 83: 47-54.

Mellaert L, Barbe'S, Anne J (2006) Clostridium spores as anti-tumour agents. Trends Microbiol 4: 190-196.

Minton NP, Mauchline ML, Lemmon MJ, Brehm JK, Fox M, Michael NP, Giaccia A, Brown JM (1995) Chemotherapeutic tumour targeting using clostridial spores. Microbiol Rev 17: 357-364.

Moriishi K, Koura M, Abe N, Fujii N, Fujinaga Y, Inoue K, Ogumad K (1996) Mosaic structures of neurotoxins produced from Clostridium botulinum strain NCTC 2916. FEMS Microbiol Lett 140: 151-158.

$\mathrm{Mu} \mathrm{Y}$, Teng H, Zhang DJ, Wang W, Xiu ZL (2006) Microbial production of 1,3-propanediol by Klebsiella pneumoniae using crude glycerol from biodiesel preparations. Biotechnol Lett 28: 1755-1759.

Nakamura CE, Whited G (2003) Metabolic engineering for the microbial production of 1,3-propanediol. Curr Opin Biotech 14: 454-459.

Nakamura Y, Miyafuji H, Kawamoto H, Saka S (2011) Acetic acid fermentability with Clostridium thermoaceticum and Clostridium thermocellum of standard compounds found in beech wood as produced in hotcompressed water. J Wood Sci 57: 331-337.

Nigel P, Minton J, Brown M, Lambin P, Anne J (2001) Clostridia in Cancer Therapy In Clostridia: biotechnology and medical applications, Bahl H, Dürre P eds, pp. 251-265 Wiley-VCH Verlag GmbH, Germany.

Oh SE, Zuo Y, Zhang H, Guiltinan MJ, Logan BE, Regan JM (2009) Hydrogen production by Clostridium acetobutylicum ATCC 824 and megaplasmid-deficient mutant M5 evaluated using a large headspace volume technique. Int J Hydrogen Energ 34: 9347-9353.

Qureshi N, Schripsema J, Lienhardt J, Blaschek HP (2000) Continuous solvent production by Clostridium beijerinckii BA101 immobilized by adsorption onto brick. World J Microb Biot 16: 377-382. 
Patyar S, Joshi R, Prasad Byrav DS, Prakash A, Medhi B, Das BK (2010) Bacteria in cancer therapy: a novel experimental strategy. J Biomed Sci 17: 17-21.

Ranade VV (1989) Drug delivery systems 1. Site-specific drug delivery using liposomes as carriers. J Cancer Pharmacol 29: 685-694.

Ren Z, Ward TE, Logan BE, Regan JM (2007) Characterization of the cellulolytic and hydrogen-producing activities of six mesophilic Clostridium species. I Appl Microbiol 103: 2258-2266.

Rosetto O, Seveso M, Caccin P, Schiavo G, Montecucco C (2001) Tetanus and botulinum neurotoxins: turning bad guys into good by research. Toxicon 39: 27-41.

Schiavo G, Matteoli M, Montecucco C (2000) Neurotoxins affecting neuroexocytosis. Physiol Rev 80: 717-766.

Shapiro RL, Hatheway C, Swerdlow DL (1998) Botulism in the United States: A Clinical and Epidemiologic Review. Ann Intern Med 129: 221-228.

Simpson LL (2000) Identification of the characteristics that underlie botulinum toxin potency: Implications for designing novel drugs. Biochimie 82: 943-953.

Skonieczny MT, Yargeau V (2009) Biohydrogen production by Clostridium beijerinckiz: effect of $\mathrm{pH}$ and substrate concentration. Int I Hydrogen Energ 34: 3288-3294.

Skrivanova E, Marounek M, Benda V, Brezina P (2006) Susceptibility of Escherichia coli, Salmonella sp. and Clostridium perfringens to organic acids and monolaurin. Vet Med-Czech 51: 81-88.

Sobel J (2005) Botulism. Clin Infect Dis 41: 1167-1173.

Song JH, Ventura JRS, Lee ChH, Jahng D (2011) Butyric Acid Production from Brown Algae Using Clostridium tyrobutyricum ATCC 25755. Biotech Bioprocess Eng 16: 42-49.

St Jean AT, Zhang M, Forbes NS (2008) Bacterial therapies: completing the cancer treatment toolbox. Curr Opin Biotech 19: 511-517.

Sun Z, Liu S (2012) Production of n-butanol from concentrated sugar maple hemicellulosic hydrolysate by Clostridia acetobutylicum ATCC824. Biomass Bioenerg 39: 39-47.
Sutcliffe RP, Sandiford NA, Khawaja HT (2005) From frown lines to fissures: Therapeutic uses for botulinum toxin. Int J Surg 3: 141-146. Tong-Long Lin A (2007) Basic pharmacology of botulinum toxin in the lower urinary tract. Tzu Chi Med J 19: 109-114.

Tracy BP, Jones SW, Fast AG, Indurthi DC, Papoutsakis ET (2012) Clostridia: the importance of their exceptional substrate and metabolite diversity for biofuel and biorefinery applications. Curr Opin Biotech 23: 364-381.

Tsui JKC (1996) Botulinum toxin as a therapeutic agent. Pharmacol Ther 72: 13-24.

Wei MQ, Mengesha A, Good D, Anne'J (2008) Bacterial targeted tumour therapy-dawn of a new era. Cancer Lett 259: 16-27.

Wheelera A, Smithb HS (2013) Botulinum toxins: Mechanisms of action, antinociception and clinical applications. Toxicology 306: 124 $-146$.

Wilkens E, Ringel AK, Hortig D, Willke T, Vorlop KD (2012) High-level production of 1,3-propanediol from crude glycerol by Clostridium butyricum AKR102a. Appl Microbiol Biot 93: 1057-1063.

Willims EA, Coxhead JM, Mathers JC (2003) Anti-cancer effects of butyrate: use of microarray technology to investigate mechanisms. Proc Nutr Soc 62: 107-115.

Wu Z, Yang SH (2003) Extractive fermentation for butyric acid production from glucose by Clostridium tyrobutyricum. Biotech Bioeng 82: 93-102.

Zhu Y, Wu Z, Yang ST (2002) Butyric acid production from acid hydrolysate of corn fibre by Clostridium tyrobutyricum in a fibrous-bed bioreactor. Process Biochem 38: 657-666.

Zigova J, Sturdik E, Dusan V, Schlosser S (1999) Butyric acid production by Clostridium butyricum with integrated extraction and pertraction. Process Biochem 34: 835-843. 